\title{
Prevalence and related risk factors of psychotic symptoms among inpatients infected with COVID-19 during the second wave pandemic
}

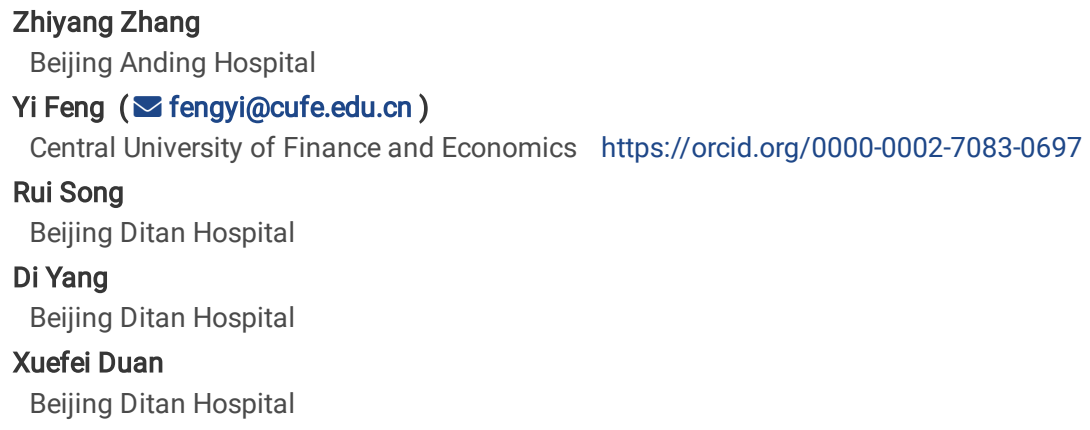

Research

Keywords: Mental health, psychotic symptoms, infected inpatients, risk factors, COVID-19

Posted Date: December 4th, 2020

DOI: https://doi.org/10.21203/rs.3.rs-120467/v1

License: @ (i) This work is licensed under a Creative Commons Attribution 4.0 International License. Read Full License

Version of Record: A version of this preprint was published at Globalization and Health on April 8th, 2021. See the published version at https://doi.org/10.1186/s12992-021-00694-4. 


\section{Abstract \\ Background}

Possibility of psychotic symptoms and related risk factors among the normal person and infected patients during the outbreak of COVID-19 has been widely investigated in previous studies. With the arrival of the second wave of the epidemic in many countries around the word, the accordingly mental health outcomes were unclear yet, especially the mental health outcomes among infected patients. It aims to explore the prevalence of and related risk factors associated with psychotic symptoms in COVID-19 infected inpatients during the second wave.

\section{Method:}

A cross-sectional survey was conducted in five isolated wards of a designated hospital in Beijing, China, from 1 July to 15 July, 2020 . The Mini-International Neuropsychiatric Interview (M.I.N.I) was conducted to assess the psychiatric disorders, and a serious of scales was used to measure self-reported psychotic symptoms and psychosomatic factors. Multivariate regression analysis was used to analyze the risk factors associated with psychotic symptoms.

\section{Results}

Among 199 infected participants, the prevalence of generalized anxiety symptoms is $51.3 \%$, of depressive symptoms $41.2 \%$, of PTSD symptoms $33.6 \%$. Loneliness, hope, coping strategies, history of mental disorders were shared risk or protective factors across several psychotic symptoms. Perceived impact by COVID-19 is the specific risk factor associated with state anxiety symptoms.

\section{Conclusions}

The prevalence of symptoms of depression, anxiety and PTSS/PTSD is high among infected inpatients during the second wave of pandemic in Beijing. Clinical doctors must realize that infected inpatients during the second wave of pandemic are likely to suffer from depressive disorder, anxiety disorders and PTSS/PTSD, as well as some neuropsychiatric syndromes. Specific mental health care is urgently needed to help inpatients cope with the virus during the second wave of pandemic.

\section{Introduction}

The world is experiencing a pandemic, the new corona virus, which first appeared in Wuhan City, Hubei Province, China in late 2019 [1]. Patients suffering from pain still suffered from major mental health issues in the reality of more and more infections and deaths. The emergency policies immediately implemented by China are early detection and isolation of suspected and confirmed cases, and the establishment of isolation units and hospitals, and others [2]. Currently, the COVID-19 pandemic was quickly under control. However, from June 10 to July 15, 2020, the second wave of COVID-19 outbreak in Beijing, China, with increased infected cases from 0 to 335 .

The general medical complications that have attracted great attention due to the corona virus disease have rarely been studied on the possible direct impact of this pandemic on mental condition and neuronophagia [3]. It is necessary for infected patients to be treated in isolated hospitals under the treatment instructions in China. For these patients suffering from autism, anger, anxiety, depressive disorder, insomnia and PTSS/PTSD, the causes of these problems may come from social isolation, surrounding risks and uncertainties, pain suffering, drug reactions, worries of contagion to others, and negative information on social networks [4]. Lots of studies have showed mental health problems such as PTSS/PTSD, anxiety and depression among health care workers or general population during the first wave of outbreak [5-8]. Few studies have investigated mental health problems among infected inpatients infected by COVID-19 during the second wave.

Our study aimed to explore the prevalence of psychotic symptoms and related risk factors among infected inpatients with COVID-19 infection during the second wave in Beijing, China.

\section{Methods}

\section{Participants and Study design}

This study was a cross-sectional design and was carried out during the second wave of COVID-19, from 1 July to 15 July, 2020 . Infected inpatients were recruited by cluster sampling in Beijing Ditan Hospital, which was the designated isolation hospital for COVID-19 infections in Beijing, China. We invited 180 inpatients from five isolated wards to participate our study, including the Mini-International Neuropsychiatric Interview and self-reported questionnaire. The Mini-International Neuropsychiatric Interview was conducted on the day before discharge from the hospital for each participant. Two experienced clinical psychiatrists conducted the systematic assessment of psychiatric symptoms by the Mini-International Neuropsychiatric Interview. 119 inpatients completed this study, with a response rate of $66.1 \%$. Participants meeting the following criteria were included: (1) inpatients infected by the COVID-19; (2) Chinese citizens who understand Chinese; (3) be infected during the second wave of pandemic in Beijing.

All participants were informed of the purpose and procedures of the study before the survey began, and completing the survey implied online informed consent to participate the investigation. This survey was approved by the Beijing Ditan Hospital Ethics Committee. 


\section{Measures}

\section{Socio-demographic characteristics}

A variety of scales and demographic data were collected in the study, including sex, age, nationality, education, clinically diagnosed type of infection, community risk (announced by Beijing municipal government during the second wave), annual income and history of mental disorder (confirmed by psychiatrist).

\section{COVID-19 related factors}

Participants were surveyed for the frequency of exposure to information or news related to COVID-19 by two items (i.e. "How many times do you browse the related information on the pandemic per day in the past two weeks?" and "How many hours do you browse the pandemic-related information per day in the past two weeks?"). The scoring criteria for such items are respectively from "0 times" to "20 times" with a total score of 21 points and from "0 hours" to "8 hours" with a total score of 8 points. The responses formed the composite score of exposure to COVID-19 related information ( $\mathrm{a}=.52$ ), with higher mean scores indicating a higher exposure to COVID-19 related information or news.

Participants were surveyed the perceived impact by COVID-19 by 4 items, including the impact on economic income, daily life, work or study, and interpersonal relationship. According to the comprehensive score of perceived impact $(a=.73)$ after different answers to these items from 1 (totally not) to 5 (to a large extent), with higher scores indicating a greater perceived impact on COVID-19 pandemic.

\section{Psychological factors}

Loneliness and hope were assessed as two psychological factors associated with psychotic symptoms. 6-Item short version of De Jong Gierveld Loneliness Scale was used to assess loneliness [9]. For each item, participants were asked to indicate the extent to which corresponding situations had happened on a 5 point scale (1 = never, $5=$ always), with Cronbach's $\alpha=0.70 \sim 0.76$. For example, "I experience a general sense of emptiness", "I miss having people around". In this study, we calculated a composite loneliness score $a=.55$, with higher scores indicating higher loneliness.

Hope was assessed by the Hope Scale, which includes 12 items concerning feeling of hope, with validated Cronbach's $a=0.74 \sim 0.84$ [10]. The Hope Scale defined hope as the process of thinking about one's goals, along with the motivation to move toward (agency subscale) and the ways to achieve (pathways scale) those goals. For example, "I energetically pursue my goals", "I can think of many ways to get out of a jam". Responses range on a 7-point scale, from 1 (definitely false) to 7 (definitely true). We calculated a composite hope score $a=.91$, with higher scores indicating higher hope.

\section{Coping strategies}

The 15-item COPE inventory was used to assess coping strategies participants used to manage their stress [11, 12]. It is comprised of 4 subscales: active coping, avoidant coping, emotion-focused coping, and acceptance coping. Participants were asked to rate how frequency they used each coping strategy on a 7-point scale from 1 (never) to 7 (always). For instance, "I concentrate my efforts on doing something about it", "I pretend that it hasn't really happened", "I discuss my feelings with someone", "I learn to live with it". In this study, the composite cope subscale score $a=0.50 \sim 0.87$, with higher scores indicating higher coping strategy in the corresponding subscale.

\section{Social supports}

Social supports were assessed by the Multidimensional Scale of Perceived Social Support (MSPSS) [13], consisting of 12 items. The MSPSS comprises three subscales, i.e., perceived support from family, from friends and from a significant other. Items includes "There is a special person who is around when I am in need", "I can talk about my problems with my friends", and so on. Each item was rated on a 7-piont Likert scale, ranging from 1 (very strongly disagree) to 7 (very strongly agree). The composite social support was calculated $\mathrm{a}=0.95$, with higher scores indicating higher perceived social supports.

\section{Psychotic symptoms}

We measured generalized anxiety, state anxiety, depression, COVID-19 related PTSD, somatization, interpersonal sensitivity, hostility, paranoid ideation and psychoticism as psychotic symptoms.

Generalized anxiety was assessed by the Generalized Anxiety Disorder Scale (GAD-7), which is a self-reported screening scale consisting of 7 items on a 4point scale, from 1 (not at all) to 4 (nearly every day), with higher total score indicating severer anxiety symptoms [14]. The Chinese version of GAD-7 has been validated and demonstrated great reliability $(a=0.89)$ [15]. In our study, the cut-off score for anxiety symptoms was 12 [15], and internal consistency is excellent $(a=0.94)$.

Compared with the generalized anxiety, we also measure the state anxiety level of inpatients while hospitalized. The State-Trait Anxiety Inventory-State (SASIS) was used to screen the situation-related anxiety, consisting of 20 items on a 4-point scale, from 1 (not at all) to 4 (very much), with higher summative score indicating higher levels of state anxiety, and had demonstrated good internal consistency $(a=0.94)[16]$. In present study, the cut-off score for state anxiety symptom was 41 [17], and the Cronbach's a was 0.91.

Similar to GAD-7, the self-screen 9-item Patient Health Questionnaire (PHQ-9) was used to assess the frequency of the occurrence of depressive symptoms over the past two weeks on a 4-point Likert scale, ranging from 1 (not at all) to 4 (nearly every day) [18]. It has been validated in China (Cronbach's a $=0.86$ ) [19], and we produced a summative score with higher scores indicating severer depressive symptoms $(a=0.91)$. We use a cut-off score at 14 in this study [18]. 
The Impact of Events Scale-Revised (IES-R) was adapted to measure COVID-19 related PTSD [20]. It consists of 22 items on a 5-piont Likert-type scale (1 = not at $a l l ; 5=$ always) to produce a summative score with higher scores indicating higher level of events-related PTSD. Participants were asked to rate the frequency with which each symptom has occurred over the past week, and the event refers to COVID-19 event in present study. IES-R has been used in previous COVID-19 studies in China [21, 22]. We calculated a COVID-19 related PTSD composite score ( $a=0.97)$, and used a cut-off score of 46 [23].

The somatization subscale, interpersonal sensitivity subscale, hostility subscale, paranoid ideation subscale and psychoticism subscale of Brief Symptom Inventory (BSI) were used to assess the five specific psychotic symptoms [24]. Respondents rank each feeling item on a 5-point scale ranging from 1 (not at all) to 5 (extremely) during the past seven days, with higher scores indicating severer sub-dimensional symptoms. The present study demonstrated great internal consistency of the five subscales $(a=0.83 \sim 0.87$ ). There were few studies providing BSI- 53 subscale cut-off scores to diagnose specific psychiatric illness to our knowledge [25].

\section{Data analysis}

We used both the Mini-International Neuropsychiatric Interview diagnostic outcome and self-reported clinical symptoms outcome to calculated the prevalence of psychotic symptoms among participants. Descriptive statistics for socio-demographic variables and M.I.N.I outcomes were first presented. Chi-square test was used to compare psychotic symptoms between males and females. Hierarchical linear regression models were used to explore the contribution of various factors to psychotic symptoms. Socio-demographic characteristics were first entered to test their relationship with psychotic symptoms in step 1 , followed by COVID-19 related factors in step 2, psychological factors in step 3, cope strategies in step 4 and social support in model 5 . In addition, we used the biascorrected bootstrap method with $95 \%$ confidence intervals to test the regression models. All analyses were performed using SPSS version 23.0 and R version 4.0.2. Statistical significance level was set at 0.05 (two-sided).

\section{Results}

\section{Socio-demographic and clinical characteristics}

The final sample comprised 119 participants. As shown in Table 1, the average age of the participants were $40.25(S D=11.50)$ years old. The majority of the patients were male (62.2\%), Han nationality (93.3\%), with lower education level (68.9\%) and annual income lower than 100,000 RMB (72.3\%). Most patients were diagnosed as "Normal" infected (84\%), and only $1.7 \%$ had history of mental disorders. According to M.I.N.I diagnosis by experienced clinical psychiatrists, $12.61 \%$ inpatients suffered from anxiety spectrum disorder, $5.9 \%$ suffered from depressive disorder, and $9.24 \%$ suffered from PTSS or PTSD. The diagnosis outcome of prevalence of psychotic symptoms by self-reported questionnaires was higher than by interview. That is, $51.3 \%$ inpatients suffered from generalized anxiety disorder, $41.2 \%$ suffered from depression, and $33.6 \%$ might suffered from PTSD.

\section{Prevalence of psychotic symptoms}

The prevalence of self-reported psychotic symptoms was high among inpatients. More than half suffered from whatever generalized anxiety (51.3\%) or state anxiety $(51.3 \%)$ symptoms. Nearly half of the patients suffered from depressive symptoms $(41.2 \%)$. As shown in Figure 1 , the inpatients with the normal infection type showed a relatively higher proportion of having psychotic symptoms, that is, $85.2 \%$ for generalized anxiety symptoms, $83.6 \%$ for state anxiety symptoms, $87.8 \%$ for depressive symptoms, and $92.5 \%$ for PTSD symptoms. Patients being 40 to 55 years old also accounts for a relatively higher proportion of psychotic symptoms. In addition, Chi-square test showed that there was no significant difference in the generalized anxiety, state anxiety or depressive symptoms between male and female $(p>.05)$. However, female inpatients showed a significant higher proportion of PTSD symptoms $\left(\chi^{2}(1)=5.53, p<.05\right)$.

\section{Associated factors with psychotic symptoms}

The results of regression showed that loneliness was the only shared risk factors across all psychotic symptoms. As shown in Table 2, apart from loneliness, hope was the shared risk factor across generalized anxiety $(\beta=0.23, p<.05)$, depression $(\beta=0.26, p<.05)$, PTSD $(\beta=0.29, p<.01)$, paranoid ideation $(\beta=$ $0.22, p<.05)$ and psychoticism symptoms $(\beta=0.18, p<.05)$. History of mental disorder was the shared risk factor across PTSD $(\beta=0.25, p<.05)$, interpersonal sensitivity $(\beta=0.31, p<.01)$, hostility $(\beta=0.48, p<.001)$, paranoid ideation $(\beta=0.58, p<.001)$, and psychoticism $(\beta=0.62, p<.001)$. Avoidant coping strategy was the shared risk factor across generalized anxiety $(\beta=0.22, p<.05)$, depression $(\beta=0.26, p<.01)$, somatization $(\beta=0.25, p<.05)$, hostility $(\beta=0.20, p<.05)$ and psychoticism $(\beta=0.22, p<.01)$. Acceptance coping was the shared protective factor across generalized anxiety $(\beta=-0.43, p<.01)$ and psychoticism $(\beta=0.30, p<.05)$. Supports from significant others was the shared risk factor across state anxiety $(\beta=0.32, p<.05)$ and depressive symptoms $(\beta=0.37, p<.05)$. Age was the shared risk factors across generalized anxiety $(\beta=0.18, p<.05)$ and PTSD symptoms $(\beta=0.23, p<.01)$. Male associated with lower PTSD $(\beta=-0.21, p<.05)$ and somatization symptoms $(\beta=-0.30, p<.01)$. In addition to shared factors, perceived impact by COVID-19 was the unique risk factor to state anxiety $(\beta=0.34, p<.001)$.

\section{Discussion}

The present study showed that at least one third of hospitalized patients exhibited symptoms of depression, anxiety, PTSD, somatization, interpersonal sensitivity, hostility, paranoid ideation or psychoticism symptoms, and the prevalence is much higher than that found in the general populations (about $20 \%$ ) [26]. The reasons why the second outbreaks showed higher mental health risks are as follows: the first reason may be that cytokines that directly or indirectly affect the brain are induced by COVID-19. For example, it has been reported that patients with severe infection in corona virus disease may cause delirium, together with various mental health problems and cerebropathy [27]. The other reason relates to the social distancing measures and quarantine policies [28]. It is necessary for infected patients to be temporarily arranged in isolated hospitals in China. Such infected patients will be more likely to suffer from autism, anger, anxiety, depressive disorder, insomnia, due to social isolation, uncertainties, drug reactions [29, 30]. 
The prevalence of psychotic symptoms among inpatients during the second wave of pandemic in Beijing is lower than the first wave in Wuhan, China. A preliminary survey at the end of January 2020 showed that more than half of the infected patients suffered from moderate to severe psychological health disorders [6]. There could be two reasons for this phenomenon. One reason may be timely mental health care was provided. In the second wave, health authority quickly dispatched psychiatrists, psychiatric nurses and clinical psychologists to support COVID-19 patients. Efforts should be made to help all patients with psychological health problems to receive professional psychotherapy and appropriate mental-health services. The other reason may be that patients have learnt more information about the COVID-19 disease from the first wave and more clear about their physic health status. It may help patients address their sense of uncertainty and fear themselves. Besides, our study found that the prevalence of mental health symptoms might be higher by use of self-report questionnaires than of M.I.N.I diagnosis, which showed that most inpatients might have psychotic symptoms but have not meet the criteria for psychotic disorders yet.

Another prominent finding is that all psychotic symptoms were associated with loneliness, which may be due to quarantine and isolation policies and lack of social support. This is basically the same as previous studies [6,28]. Isolation can have negative effects on the mental health of children and adults [31, 32]. People who receive isolation often dislike isolation, because it means that they are separated from their loved ones, lose freedom, are not sure about their illness at home, and feel bored. All these factors may increase their loneliness. Officials should specify that the time of individual isolation meets the requirements, provide clear reasons for isolation and information on relevant agreements, and ensure that adequate supplies would be provided to the isolated personnel. In addition, we found that avoidant coping strategy was risk factor whereas acceptance coping strategy was protective factor for some psychotic symptoms. It indicates that inpatients should be encouraged to accept the infected situations and not to get through it by avoiding it. Furthermore, we found that hope is a risk factor for some symptoms. One possible explanation is that individuals with more hope are hard to accept terrible situations and tend to avoid the reality [10]. Besides, the results showed that supports from significant others may increase inpatients' state anxiety and depression. It reminds us that too much unnecessary care, especially from people who are not family or friends but significant others (e.g., medical workers, colleagues, bosses) could make patients induce more anxious about their illness. Thus, "moderate" care is needed for infected patients.

Moreover, the sociodemographic information suggests that age and gender also influence mental health among inpatients during the second wave of pandemic. Elderly and female inpatients, in particular, suffers greater psychological impact of the pandemic as well as higher levels of PTSS/PTSD, anxiety, depression and other psychotic symptoms. Consistent with prior studies, COVID-19 is known to exhibit a particularly severe course in the advanced age and individuals with accompanying chronic disease [31-33]. Therefore, elderly people exposed to COVID-19 may be more severely affected. In the second wave, most infected patients were 40 or above years old, who might be more susceptible to mental disorders. Females has been identified as the most potent predictor of PTSD symptoms after pandemic [34], and our results showed that PTSD and somatization symptoms were higher in female participants, which is consistent with previous studies. In addition, we found that COVID-19 related factors were not predominant factor associated with psychotic symptoms. For instance, exposure to COVID-19 related information or news shows no significant relation across all psychotic symptoms, indicating that psychotic symptoms relates to more stable variables, such as history of mental disorders.

This study has several limitations. First, the sample size was not large enough, due to limited positive cases (331 in total) during the second wave in Beijing. Second, due to the lack of baseline psychiatric assessment, we cannot accurately estimate the incidence rate, and we rely on the point prevalence rate when conditions permit. Third, our study does not include objective biological indicators, such as peripheral blood heredity, inflammation, immune and metabolic function markers, cerebrospinal fluid indicators, EEG or brain imaging.

\section{Conclusions}

In summary, this study investigated the prevalence of psychotic symptoms and related risk factors among hospitalized patients with COVID-19 infection during the second wave of pandemic outbreak. Clinicians must be aware that hospitalized patients may suffer higher depression, anxiety, post-traumatic stress disorder, and other neuropsychiatric syndrome. Therefore, we urgently need to provide infected patients with specific mental health interventions and resources to help them cope with the virus and solve the corresponding mental health problems.

\section{Declarations}

\section{Ethics approval and consent to participate}

All participants were informed of the purpose and procedure of the study prior to the survey. All participants completed the online informed consent before completing the survey. The Beijing Ditan Hospital Ethics Committee has approved this investigation (No: 2020-011-01).

\section{Consent for publication}

Not applicable. All participants participated in the survey anonymously.

\section{Availability of data and materials}

The datasets used during the current study are available from the corresponding author on reasonable request.

\section{Competing interests}

The authors declare that they have no competing interests.

\section{Funding}


This study was funded by National Major Science and Technology Projects of China (Grant No. 2018ZX10715-005) and Beijing Municipal Administration of Hospitals Clinical Medicine Development of Special Funding Support (Grant No. ZYLX201807).

\section{Author's contributions}

All authors contributed significantly to the concept of this study. ZYZ, YF and XFD designed the study; ZYZ and XFD conducted the study and collected data; YF analysed and interpreted data; ZYZ and YF drafted the manuscript and all author contributed to revise it. All authors read and approved the final manuscript.

\section{Acknowledgements}

We acknowledged Tuozhen Liu to help data visualization. We also thank all the participants who participated in this study.

\section{References}

1. Huang C, Wang Y, Li X, Ren L, Zhao J, Hu Y, et al. Clinical features of patients infected with 2019 novel coronavirus in Wuhan, China. Lancet (London, England). 2020;395(10223):497-506.

2. Wang C, Horby PW, Hayden FG, Gao GF. A novel coronavirus outbreak of global health concern. Lancet (London, England). 2020;395(10223):470-3.

3. Vindegaard N, Benros ME. COVID-19 pandemic and mental health consequences: Systematic review of the current evidence. Brain, behavior, and immunity. 2020;89:531-42.

4. Xiang YT, Yang Y, Li W, Zhang L, Zhang Q, Cheung T, et al. Timely mental health care for the 2019 novel coronavirus outbreak is urgently needed. The lancet Psychiatry. 2020;7(3):228-9.

5. Zhang J, Lu H, Zeng H, Zhang S, Du Q, Jiang T, et al. The differential psychological distress of populations affected by the COVID-19 pandemic. Brain, behavior, and immunity. 2020;87:49-50.

6. Shi L, Lu ZA, Que JY, Huang XL, Liu L, Ran MS, et al. Prevalence of and Risk Factors Associated With Mental Health Symptoms Among the General Population in China During the Coronavirus Disease 2019 Pandemic. JAMA network open. 2020;3(7):e2014053.

7. Özdin S, Bayrak Özdin Ş. Levels and predictors of anxiety, depression and health anxiety during COVID-19 pandemic in Turkish society: The importance of gender. The International journal of social psychiatry. 2020;66(5):504-11.

8. Feng Y, Zong M, Yang Z, Gu W, Dong D, Qiao Z. When altruists cannot help: The influence of altruism on the mental health of university students during the COVID-19 pandemic. Globalization and Health. 2020;16(61):1-8.

9. Gierveld JDJ, Tilburg TV. A 6-Item scale for overall, emotional, and social loneliness: Confirmatory tests on survey data. Research on Aging. 2006;28(5):582-98.

10. Snyder CR. Conceptualizing, measuring, and nurturing hope. Journal of Counseling \& Development. 1995;73(3):355-60.

11. Carver CS, Scheier MF, Weintraub JK. Assessing coping strategies: A theoretically based approach. Journal of Personality and Social Psychology. 1989;56:267-83

12. Phelps SB, Jarvis PA. Coping in adolescence: Empirical evidence for a theoretically based approach to assessing coping. Journal of Youth and Adolescence. 1994;23(3):359-71.

13. Zimet GD, Dahlem NW, Zimet SG, Farley GK. The multidimensional scale of perceived social support. Journal of Personality Assessment. 1988;52(1):3041.

14. Spitzer RL, Kroenke K, Williams JBW, Lowe B. A brief measure for assessing generalized anxiety disorder: The GAD-7. Arch Intern Med. 2006;166(10):1092-7.

15. Tong X, An D, McGonigal A, Park S-P, Zhou D. Validation of the Generalized Anxiety Disorder-7 (GAD-7) among Chinese people with epilepsy. Epilepsy Research. 2016;120:31-6.

16. Spielberger CD, Gorsuch RL, Lushene RE, Vagg PR, Jacobs GA. Manual for the State-Trait Anxiety Inventory STAI (Form Y). Palo Alto, CA: Consulting Psychologists Press; 1983.

17. Dennis C-L, Coghlan M, Vigod S. Can we identify mothers at-risk for postpartum anxiety in the immediate postpartum period using the State-Trait Anxiety Inventory? Journal of Affective Disorders. 2013;150(3):1217-20.

18. Kurt Kroenke, Spitzer RL. The PHQ-9: A new depression diagnostic and severity measure. Psychiatric Annals. 2002;32(9):509-15.

19. Wang W, Bian Q, Zhao Y, Li X, Wang W, Du J, et al. Reliability and validity of the Chinese version of the Patient Health Questionnaire (PHQ-9) in the general population. General Hospital Psychiatry. 2014;36(5):539-44.

20. Weiss DS. The impact of event scale: revised. In: J.P. W, C.S. T, editors. Cross-Cultural Assessment of Psychological Trauma and PTSD International and Cultural Psychology Series. Boston, MA: Springer; 2007. p. 219-38.

21. Tan W, Hao F, McIntyre RS, Jiang L, Jiang X, Zhang L, et al. Is returning to work during the COVID-19 pandemic stressful? A study on immediate mental health status and psychoneuroimmunity prevention measures of Chinese workforce. Brain, Behavior, and Immunity. 2020;87:84-92.

22. Wang Y, Duan Z, Ma Z, Mao Y, Li X, Wilson A, et al. Epidemiology of mental health problems among patients with cancer during COVID-19 pandemic. Translational Psychiatry. 2020;10(1):1-10.

23. Su Z, Jiang X, Wang C, Liu J, Chen Y, Li Q, et al. Differential effects of nerve growth factor on expression of dopamine 2 receptor subtypes in GH3 rat pituitary tumor cells. Endocrine. 2012;42(3):670-5. 
24. Boulet J, Boss MW. Reliability and validity of the Brief Symptom Inventory. Psychological Assessment: A Journal of Consulting and Clinical Psychology. 1991;3(3):433-7.

25. Ruckenstein MJ, Staab JP. The Basic Symptom Inventory-53 and its use in the management of pastients with psychogenic dizziness. OtolaryngologyHead and Neck Surgery. 2001;125(5):533-6.

26. Wang C, Pan R, Wan X, Tan Y, Xu L, Mclntyre RS, et al. A longitudinal study on the mental health of general population during the COVID-19 epidemic in China. Brain, behavior, and immunity. 2020;87:40-8.

27. Andrews LJ, Benken ST. COVID-19: ICU delirium management during SARS-CoV-2 pandemic-pharmacological considerations. Critical care (London, England). 2020;24(1):375.

28. Brooks SK, Webster RK, Smith LE, Woodland L, Wessely S, Greenberg N, et al. The psychological impact of quarantine and how to reduce it: rapid review of the evidence. Lancet (London, England). 2020;395(10227):912-20.

29. Lin CY, Peng YC, Wu YH, Chang J, Chan CH, Yang DY. The psychological effect of severe acute respiratory syndrome on emergency department staff. Emergency medicine journal : EMJ. 2007;24(1):12-7.

30. Bo HX, Li W, Yang Y, Wang Y, Zhang Q, Cheung T, et al. Posttraumatic stress symptoms and attitude toward crisis mental health services among clinically stable patients with COVID-19 in China. Psychological medicine. 2020:1-2.

31. Zhou J, Liu L, Xue P, Yang X, Tang X. Mental Health Response to the COVID-19 Outbreak in China. The American journal of psychiatry. 2020;177(7):574-5.

32. Zhou F, Yu T, Du R, Fan G, Liu Y, Liu Z, et al. Clinical course and risk factors for mortality of adult inpatients with COVID-19 in Wuhan, China: a retrospective cohort study. Lancet (London, England). 2020;395(10229):1054-62.

33. Fernández-Aranda F, Casas M, Claes L, Bryan DC, Favaro A, Granero R, et al. COVID-19 and implications for eating disorders. European eating disorders review : the journal of the Eating Disorders Association. 2020;28(3):239-45.

34. Liu N, Zhang F, Wei C, Jia Y, Shang Z, Sun L, et al. Prevalence and predictors of PTSS during COVID-19 outbreak in China hardest-hit areas: Gender differences matter. Psychiatry research. 2020;287:112921.

\section{Tables}

Table 1. Socio-demographic and clinical characteristics of the study sample $(N=119)$ 


\begin{tabular}{|c|c|c|}
\hline Variables & Number $(n)$ & Percent (\%) \\
\hline Mean age $(S D)$ & \multicolumn{2}{|c|}{$40.25 \pm 11.50$} \\
\hline \multicolumn{3}{|l|}{ Sex } \\
\hline Male & 74 & 62.2 \\
\hline Female & 45 & 37.8 \\
\hline \multicolumn{3}{|l|}{ Nationality } \\
\hline Han & 111 & 93.3 \\
\hline Others & 8 & 6.7 \\
\hline \multicolumn{3}{|l|}{ Education level } \\
\hline Junior school or lower & 82 & 68.9 \\
\hline High school & 21 & 17.7 \\
\hline College or above & 16 & 13.4 \\
\hline \multicolumn{3}{|l|}{ Annual income } \\
\hline$<30,000$ & 31 & 26.1 \\
\hline $30,000 \sim 60,000$ & 33 & 27.7 \\
\hline $70,000 \sim 100,000$ & 22 & 18.5 \\
\hline $100,000 \sim 150,000$ & 16 & 13.4 \\
\hline$>150,000$ & 17 & 14.3 \\
\hline \multicolumn{3}{|l|}{ Community risk } \\
\hline No risk & 2 & 1.7 \\
\hline Low risk & 16 & 13.4 \\
\hline Moderate risk & 44 & 37.0 \\
\hline High risk & 57 & 47.9 \\
\hline \multicolumn{3}{|l|}{ Type of infection } \\
\hline Asymptomatic & 5 & 4.2 \\
\hline Light & 14 & 11.8 \\
\hline Normal & 100 & 84.0 \\
\hline Severe & 0 & 0 \\
\hline \multicolumn{3}{|l|}{ History of mental disorder } \\
\hline Yes & 2 & 1.7 \\
\hline No & 117 & 98.3 \\
\hline \multicolumn{3}{|l|}{ M.I.N.I diagnosis } \\
\hline Anxiety spectrum disorder & 15 & 12.61 \\
\hline Depressive disorder & 7 & 5.9 \\
\hline PTSS/PTSD & 11 & 9.24 \\
\hline Manic episode & 2 & 1.68 \\
\hline Obsessive-compulsive disorder & 3 & 2.52 \\
\hline \multicolumn{3}{|l|}{ Self-reported Scale diagnosis } \\
\hline Generalized anxiety symptoms & 61 & 51.3 \\
\hline State anxiety symptoms & 61 & 51.3 \\
\hline Depressive symptoms & 49 & 41.2 \\
\hline PTSD symptoms & 40 & 33.6 \\
\hline
\end{tabular}

Note. The unit of annual income is RMB yuan. PTSD: posttraumatic stress disorder. 
Table 2. Hierarchical linear regression coefficients for different psychotic symptoms $(N=119)$

\begin{tabular}{|c|c|c|c|c|c|c|c|c|c|c|c|c|c|c|}
\hline \multirow[t]{2}{*}{ Variables } & \multicolumn{5}{|c|}{ Model of generalized anxiety } & \multicolumn{5}{|c|}{ Model of state anxiety } & \multicolumn{4}{|c|}{ Model of depression } \\
\hline & $\begin{array}{l}\text { Model } \\
1\end{array}$ & $\begin{array}{l}\text { Model } \\
2\end{array}$ & $\begin{array}{l}\text { Model } \\
3\end{array}$ & $\begin{array}{l}\text { Model } \\
4\end{array}$ & $\begin{array}{l}\text { Model } \\
5\end{array}$ & $\begin{array}{l}\text { Model } \\
1\end{array}$ & $\begin{array}{l}\text { Model } \\
2\end{array}$ & $\begin{array}{l}\text { Model } \\
3\end{array}$ & $\begin{array}{l}\text { Model } \\
4\end{array}$ & $\begin{array}{l}\text { Model } \\
5\end{array}$ & $\begin{array}{l}\text { Model } \\
1\end{array}$ & $\begin{array}{l}\text { Model } \\
2\end{array}$ & $\begin{array}{l}\text { Model } \\
3\end{array}$ & $\begin{array}{l}\text { Model } \\
4\end{array}$ \\
\hline \multicolumn{15}{|c|}{ Socio-demographics characteristics } \\
\hline Age & $0.22 *$ & $0.01 *$ & 0.17 & $0.17 *$ & $0.18 *$ & 0.05 & 0.10 & 0.07 & 0.03 & 0.03 & $0.19 *$ & $0.21 *$ & 0.14 & 0.12 \\
\hline $\begin{array}{l}\text { Nationality } \\
\text { (Han) }\end{array}$ & -0.05 & -0.17 & -0.04 & -0.07 & -0.08 & 0.07 & 0.03 & 0.01 & -0.02 & -0.04 & -0.01 & -0.03 & -0.01 & -0.04 \\
\hline $\begin{array}{l}\text { Education } \\
\text { level }\end{array}$ & 0.01 & 0.01 & 0.04 & 0.05 & 0.04 & -0.04 & 0.00 & 0.11 & 0.13 & 0.12 & -0.02 & 0.00 & 0.04 & 0.05 \\
\hline $\begin{array}{l}\text { Annual } \\
\text { income }\end{array}$ & -0.02 & -0.00 & -0.07 & -0.07 & -0.05 & -0.06 & -0.04 & -0.08 & -0.10 & -0.07 & -0.08 & -0.07 & -0.14 & -0.13 \\
\hline $\begin{array}{l}\text { Community } \\
\text { risk }\end{array}$ & $0.23^{\star}$ & $0.16 *$ & 0.13 & 0.15 & 0.16 & 0.14 & 0.05 & 0.06 & 0.06 & 0.08 & 0.17 & 0.13 & 0.07 & 0.07 \\
\hline $\begin{array}{l}\text { Infection } \\
\text { type }\end{array}$ & -0.03 & -0.04 & -0.03 & -0.02 & -0.04 & -0.07 & -0.09 & -0.07 & -0.04 & -0.05 & -0.03 & -0.04 & -0.04 & -0.03 \\
\hline $\begin{array}{l}\text { History of } \\
\text { mental } \\
\text { disorder } \\
\text { (yes) }\end{array}$ & $0.27 * \star$ & 1.19* & 0.09 & 0.09 & 0.14 & $0.26 * \star$ & $0.20 *$ & 0.08 & 0.07 & 0.12 & $0.23^{\star}$ & $0.21 *$ & 0.04 & 0.03 \\
\hline \multicolumn{15}{|c|}{ COVID-19 related factors } \\
\hline $\begin{array}{l}\text { Exposure to } \\
\text { news }\end{array}$ & lated & 0.01 & 0.03 & 0.07 & 0.06 & & 0.04 & 0.06 & 0.05 & 0.04 & & 0.02 & 0.01 & 0.02 \\
\hline $\begin{array}{l}\text { Perceived im } \\
\text { pandemic }\end{array}$ & act by & $0.19 *$ & $0.17 *$ & 0.15 & 0.16 & & $0.45^{\star \star \star}$ & $0.37 * \star \star$ & $0.32^{\star \star \star}$ & $0.34^{\star \star \star}$ & & $0.20 \star$ & 0.16 & 0.12 \\
\hline Loneliness & & & $0.43^{\star \star \star}$ & $0.37 * \star \star$ & 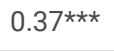 & & & $0.33^{\star \star \star}$ & $0.29 * \star \star$ & $0.26 \star \star$ & & & $0.48 * \star \star$ & $0.44^{\star *}$ \\
\hline Hope & & & $0.27 * \star$ & $0.22^{\star}$ & $0.23^{\star}$ & & & -0.09 & -0.01 & 0.02 & & & $0.23^{\star}$ & $0.24 *$ \\
\hline \multicolumn{15}{|c|}{ Coping strategies } \\
\hline $\begin{array}{l}\text { Active } \\
\text { coping }\end{array}$ & & & & 0.10 & 0.11 & & & & -0.22 & -0.22 & & & & 0.02 \\
\hline $\begin{array}{l}\text { Avoidant } \\
\text { coping }\end{array}$ & & & & $0.21 *$ & $0.22 *$ & & & & 0.16 & 0.18 & & & & $0.25^{\star}$ \\
\hline $\begin{array}{l}\text { Emotion-focl } \\
\text { coping }\end{array}$ & & & & $0.24^{\star}$ & 0.20 & & & & 0.11 & 0.08 & & & & -0.03 \\
\hline $\begin{array}{l}\text { Acceptance } \\
\text { coping }\end{array}$ & & & & -0.40 & $-0.43^{\star \star}$ & & & & -0.17 & -0.21 & & & & -0.15 \\
\hline \multicolumn{15}{|c|}{ Social support } \\
\hline $\begin{array}{l}\text { Family } \\
\text { support }\end{array}$ & & & & & -0.13 & & & & & -0.21 & & & & \\
\hline $\begin{array}{l}\text { Friends } \\
\text { support }\end{array}$ & & & & & 0.006 & & & & & -0.10 & & & & \\
\hline $\begin{array}{l}\text { Significant o } \\
\text { support }\end{array}$ & her & & & & 0.21 & & & & & $0.32^{\star}$ & & & & \\
\hline $\begin{array}{l}\text { Adjusted } \\
R^{2}\end{array}$ & 0.096 & 0.117 & 0.277 & 0.334 & 0.326 & 0.031 & 0.205 & 0.308 & 0.365 & 0.375 & 0.064 & 0.085 & 0.271 & 0.291 \\
\hline$\Delta R^{2}$ & & 0.021 & 0.160 & 0.057 & -0.01 & & 0.17 & 0.10 & 0.06 & 0.01 & & 0.02 & 0.19 & 0.02 \\
\hline
\end{tabular}

Table 2. Hierarchical linear regression coefficients for different psychotic symptoms $(N=119)$ continued 


\begin{tabular}{|c|c|c|c|c|c|c|c|c|c|c|c|c|c|c|}
\hline \multirow[t]{2}{*}{ Variables } & \multicolumn{5}{|c|}{ Model of PTSD } & \multicolumn{5}{|c|}{ Model of somatization } & \multicolumn{4}{|c|}{ Model of interpersonal sensitivity } \\
\hline & $\begin{array}{l}\text { Model } \\
1\end{array}$ & $\begin{array}{l}\text { Model } \\
2\end{array}$ & $\begin{array}{l}\text { Model } \\
3\end{array}$ & $\begin{array}{l}\text { Model } \\
4\end{array}$ & $\begin{array}{l}\text { Model } \\
5\end{array}$ & $\begin{array}{l}\text { Model } \\
1\end{array}$ & $\begin{array}{l}\text { Model } \\
2\end{array}$ & $\begin{array}{l}\text { Model } \\
3\end{array}$ & $\begin{array}{l}\text { Model } \\
4\end{array}$ & $\begin{array}{l}\text { Model } \\
5\end{array}$ & $\begin{array}{l}\text { Model } \\
1\end{array}$ & $\begin{array}{l}\text { Model } \\
2\end{array}$ & $\begin{array}{l}\text { Model } \\
3\end{array}$ & $\begin{array}{l}\text { Mod } \\
4\end{array}$ \\
\hline \multicolumn{15}{|c|}{ Socio-demographics characteristics } \\
\hline Age & $0.28^{\star \star}$ & $0.29 \star \star$ & $0.22^{\star \star}$ & $0.22^{\star \star}$ & $0.23^{\star \star}$ & 0.14 & 0.14 & 0.10 & 0.10 & 0.10 & -0.01 & 0.00 & -0.06 & $-0.0 \epsilon$ \\
\hline Sex (male) & -0.12 & -0.14 & $-0.20 *$ & $-0.21^{\star}$ & $-0.21^{\star}$ & $-0.21^{\star}$ & $-0.22^{\star}$ & $-0.25^{\star \star}$ & $-0.30 \star \star$ & $-0.30 \star \star$ & -0.07 & -0.08 & -0.12 & -0.12 \\
\hline $\begin{array}{l}\text { Nationality } \\
\text { (Han) }\end{array}$ & -0.02 & -0.03 & 0.01 & -0.01 & -0.02 & 0.13 & 0.12 & 0.14 & 0.11 & 0.10 & -0.02 & -0.03 & -0.02 & $-0.0 \leftleftarrows$ \\
\hline $\begin{array}{l}\text { Education } \\
\text { level }\end{array}$ & 0.07 & 0.08 & 0.05 & 0.06 & 0.06 & -0.04 & -0.04 & -0.01 & -0.02 & -0.00 & -0.15 & -0.14 & -0.10 & $-0.0 \varepsilon$ \\
\hline $\begin{array}{l}\text { Annual } \\
\text { income }\end{array}$ & -0.03 & -0.02 & -0.07 & -0.06 & -0.06 & -0.01 & -0.00 & -0.05 & -0.00 & -0.01 & -0.05 & -0.05 & -0.11 & -0.12 \\
\hline $\begin{array}{l}\text { Community } \\
\text { risk }\end{array}$ & $0.19 *$ & 0.17 & 0.09 & 0.10 & 0.10 & 0.13 & 0.12 & 0.08 & 0.10 & 0.11 & 0.16 & 0.14 & 0.09 & 0.09 \\
\hline $\begin{array}{l}\text { Infection } \\
\text { type }\end{array}$ & 0.05 & 0.05 & 0.04 & 0.05 & 0.03 & 0.13 & 0.13 & 0.13 & 0.13 & 0.09 & 0.01 & 0.01 & 0.01 & 0.04 \\
\hline $\begin{array}{l}\text { History of } \\
\text { mental } \\
\text { disorder } \\
\text { (yes) }\end{array}$ & $0.37^{\star \star \star}$ & $0.36^{* \star *}$ & $0.23^{\star \star}$ & $0.22^{\star}$ & $0.25^{\star}$ & 0.03 & 0.02 & -0.09 & -0.07 & -0.05 & $0.47^{\star \star \star}$ & $0.46^{\star \star \star}$ & 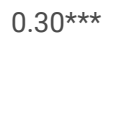 & 0.28 \\
\hline \multicolumn{15}{|c|}{ COVID-19 related factors } \\
\hline $\begin{array}{l}\text { Exposure to } r \\
\text { news }\end{array}$ & elated & 0.07 & 0.05 & 0.07 & 0.07 & & 0.02 & 0.02 & 0.06 & 0.06 & & 0.02 & 0.01 & 0.05 \\
\hline $\begin{array}{l}\text { Perceived im } \\
\text { pandemic }\end{array}$ & act by & 0.15 & 0.15 & 0.14 & 0.14 & & 0.05 & 0.02 & 0.01 & -0.00 & & 0.10 & 0.06 & 0.04 \\
\hline \multicolumn{15}{|c|}{ Psychological factors } \\
\hline Loneliness & & & $0.36 * * \star$ & $0.34 * \star \star$ & $0.34 * \star \star$ & & & $0.31^{\star \star}$ & $0.24^{\star}$ & $0.23^{\star}$ & & & $0.44^{\star \star \star}$ & 0.42 \\
\hline Hope & & & $0.33^{\star \star \star}$ & $0.28 * \star$ & $0.29 * *$ & & & 0.15 & 0.12 & 0.13 & & & $0.19 *$ & 0.12 \\
\hline \multicolumn{15}{|c|}{ Coping strategies } \\
\hline $\begin{array}{l}\text { Active } \\
\text { coping }\end{array}$ & & & & 0.08 & 0.08 & & & & $0.31 *$ & 0.28 & & & & -0.01 \\
\hline $\begin{array}{l}\text { Avoidant } \\
\text { coping }\end{array}$ & & & & 0.13 & 0.13 & & & & $0.24 *$ & $0.25^{\star}$ & & & & 0.15 \\
\hline $\begin{array}{l}\text { Emotion-focu } \\
\text { coping }\end{array}$ & & & & 0.07 & 0.04 & & & & -0.01 & -0.08 & & & & 0.22 \\
\hline $\begin{array}{l}\text { Acceptance } \\
\text { coping }\end{array}$ & & & & -0.14 & -0.15 & & & & $-0.37 *$ & -0.36 & & & & $-0.1 \varepsilon$ \\
\hline \multicolumn{15}{|c|}{ Social support } \\
\hline $\begin{array}{l}\text { Family } \\
\text { support }\end{array}$ & & & & & -0.03 & & & & & 0.07 & & & & \\
\hline $\begin{array}{l}\text { Friends } \\
\text { support }\end{array}$ & & & & & -0.06 & & & & & -0.29 & & & & \\
\hline $\begin{array}{l}\text { Significant ot } \\
\text { support }\end{array}$ & & & & & 0.14 & & & & & 0.32 & & & & \\
\hline $\begin{array}{l}\text { Adjusted } \\
R^{2}\end{array}$ & 0.191 & 0.198 & 0.344 & 0.339 & 0.324 & 0.049 & 0.034 & 0.102 & 0.140 & 0.149 & 0.213 & 0.209 & 0.365 & 0.39 \\
\hline$\Delta R^{2}$ & & 0.01 & 0.15 & -0.01 & -0.01 & & -0.02 & 0.07 & 0.04 & 0.01 & & -0.00 & 0.15 & 0.03 \\
\hline
\end{tabular}

Table 2. Hierarchical linear regression coefficients for different psychotic symptoms $(N=119)$ continued 


\begin{tabular}{|c|c|c|c|c|c|c|c|c|c|c|c|c|c|c|}
\hline \multirow[t]{2}{*}{ Variables } & \multicolumn{5}{|c|}{ Model of hostility } & \multicolumn{5}{|c|}{ Model of paranoid ideation } & \multicolumn{4}{|c|}{ Model of psychoticism } \\
\hline & $\begin{array}{l}\text { Model } \\
1\end{array}$ & $\begin{array}{l}\text { Model } \\
2\end{array}$ & $\begin{array}{l}\text { Model } \\
3\end{array}$ & $\begin{array}{l}\text { Model } \\
4\end{array}$ & $\begin{array}{l}\text { Model } \\
5\end{array}$ & $\begin{array}{l}\text { Model } \\
1\end{array}$ & $\begin{array}{l}\text { Model } \\
2\end{array}$ & $\begin{array}{l}\text { Model } \\
3\end{array}$ & $\begin{array}{l}\text { Model } \\
4\end{array}$ & $\begin{array}{l}\text { Model } \\
5\end{array}$ & $\begin{array}{l}\text { Model } \\
1\end{array}$ & $\begin{array}{l}\text { Model } \\
2\end{array}$ & $\begin{array}{l}\text { Model } \\
3\end{array}$ & $\hat{4}$ \\
\hline \multicolumn{15}{|c|}{ Socio-demographics characteristics } \\
\hline Age & 0.02 & 0.04 & -0.01 & -0.01 & -0.01 & 0.06 & 0.08 & 0.02 & 0.02 & 0.03 & 0.06 & 0.07 & 0.01 & $\mathrm{C}$ \\
\hline Sex (male) & 0.00 & -0.00 & -0.03 & -0.03 & -0.03 & -0.00 & -0.01 & -0.06 & -0.08 & -0.07 & 0.02 & 0.01 & -0.03 & -1 \\
\hline $\begin{array}{l}\text { Nationality } \\
\text { (Han) }\end{array}$ & -0.10 & -0.11 & -0.10 & -0.12 & -0.12 & 0.03 & 0.01 & 0.04 & 0.03 & 0.02 & -0.02 & -0.03 & -0.01 & -1 \\
\hline $\begin{array}{l}\text { Education } \\
\text { level }\end{array}$ & -0.15 & -0.13 & -0.11 & -0.09 & -0.08 & -0.13 & -0.11 & -0.11 & -0.11 & -0.12 & -0.13 & -0.12 & -0.09 & -1 \\
\hline $\begin{array}{l}\text { Annual } \\
\text { income }\end{array}$ & 0.02 & 0.02 & -0.03 & -0.03 & -0.03 & 0.02 & 0.02 & -0.04 & -0.03 & -0.01 & 0.02 & 0.03 & -0.03 & -1 \\
\hline $\begin{array}{l}\text { Community } \\
\text { risk }\end{array}$ & 0.12 & 0.09 & 0.05 & 0.06 & 0.06 & 0.11 & 0.08 & 0.02 & 0.03 & 0.04 & 0.10 & 0.08 & 0.03 & C \\
\hline $\begin{array}{l}\text { Infection } \\
\text { type }\end{array}$ & -0.01 & -0.02 & -0.01 & 0.01 & -0.01 & -0.00 & -0.01 & -0.01 & -0.01 & -0.02 & -0.09 & -0.10 & -0.09 & -1 \\
\hline $\begin{array}{l}\text { History of } \\
\text { mental } \\
\text { disorder } \\
\text { (yes) }\end{array}$ & 0.61 *** & 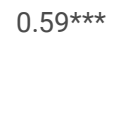 & $0.48^{\star \star \star}$ & $0.47^{\star \star \star}$ & $0.48^{\star \star \star}$ & $0.68^{* \star *}$ & $0.66^{\star \star \star}$ & $0.53^{\star \star \star}$ & $0.54^{\star \star \star}$ & $0.58^{\star \star \star}$ & $0.72^{\star \star \star}$ & $0.71^{\star \star \star}$ & $0.57^{\star \star \star}$ & C \\
\hline \multicolumn{15}{|l|}{$\begin{array}{l}\text { COVID-19 } \\
\text { related } \\
\text { factors }\end{array}$} \\
\hline $\begin{array}{l}\text { Exposure to re } \\
\text { news }\end{array}$ & elated & -0.07 & -0.07 & -0.04 & -0.04 & & -0.03 & -0.05 & -0.02 & -0.03 & & 0.00 & -0.01 & C \\
\hline $\begin{array}{l}\text { Perceived imp } \\
\text { pandemic }\end{array}$ & act by & 0.11 & 0.08 & 0.06 & 0.05 & & 0.13 & 0.11 & 0.11 & 0.12 & & 0.09 & 0.06 & C \\
\hline \multicolumn{15}{|c|}{ Psychological factors } \\
\hline Loneliness & & & $0.31 * \star \star$ & $0.27^{\star \star \star}$ & $0.27 * \star$ & & & $0.36^{\star \star \star}$ & $0.33^{\star \star \star}$ & $0.32^{\star \star \star}$ & & & $0.37 * \star \star$ & $\mathrm{C}$ \\
\hline Hope & & & 0.14 & 0.10 & 0.10 & & & $0.25^{\star \star}$ & $0.21^{\star}$ & $0.22^{\star}$ & & & $0.19 * *$ & C \\
\hline \multicolumn{15}{|c|}{ Coping strategies } \\
\hline $\begin{array}{l}\text { Active } \\
\text { coping }\end{array}$ & & & & 0.00 & -0.01 & & & & 0.10 & 0.10 & & & & C \\
\hline $\begin{array}{l}\text { Avoidant } \\
\text { coping }\end{array}$ & & & & $0.20 *$ & $0.20 *$ & & & & 0.07 & 0.07 & & & & C \\
\hline $\begin{array}{l}\text { Emotion-focu } \\
\text { coping }\end{array}$ & & & & 0.20 & 0.16 & & & & 0.16 & 0.14 & & & & C \\
\hline $\begin{array}{l}\text { Acceptance } \\
\text { coping }\end{array}$ & & & & -0.25 & -0.24 & & & & -0.23 & -0.26 & & & & -1 \\
\hline \multicolumn{15}{|l|}{$\begin{array}{l}\text { Social } \\
\text { support }\end{array}$} \\
\hline $\begin{array}{l}\text { Family } \\
\text { support }\end{array}$ & & & & & 0.05 & & & & & -0.14 & & & & \\
\hline $\begin{array}{l}\text { Friends } \\
\text { support }\end{array}$ & & & & & -0.12 & & & & & -0.01 & & & & \\
\hline $\begin{array}{l}\text { Significant ot } \\
\text { support }\end{array}$ & & & & & 0.14 & & & & & 0.17 & & & & \\
\hline $\begin{array}{l}\text { Adjusted } \\
R^{2}\end{array}$ & 0.367 & 0.374 & 0.445 & 0.487 & 0.479 & 0.402 & 0.411 & 0.531 & 0.535 & 0.529 & 0.482 & 0.480 & 0.597 & C \\
\hline$\Delta R^{2}$ & & 0.01 & 0.07 & 0.04 & -0.01 & & 0.01 & 0.12 & 0.00 & -0.01 & & -0.00 & 0.12 & C \\
\hline
\end{tabular}

Note. The regression coefficients in the above table were all standardized regression coefficients. ${ }^{\star} p<.05 ;{ }^{* \star} p<.01 ;{ }^{* \star} p<.001$.

Figures 
(a) the number of generalized anxiety symptoms

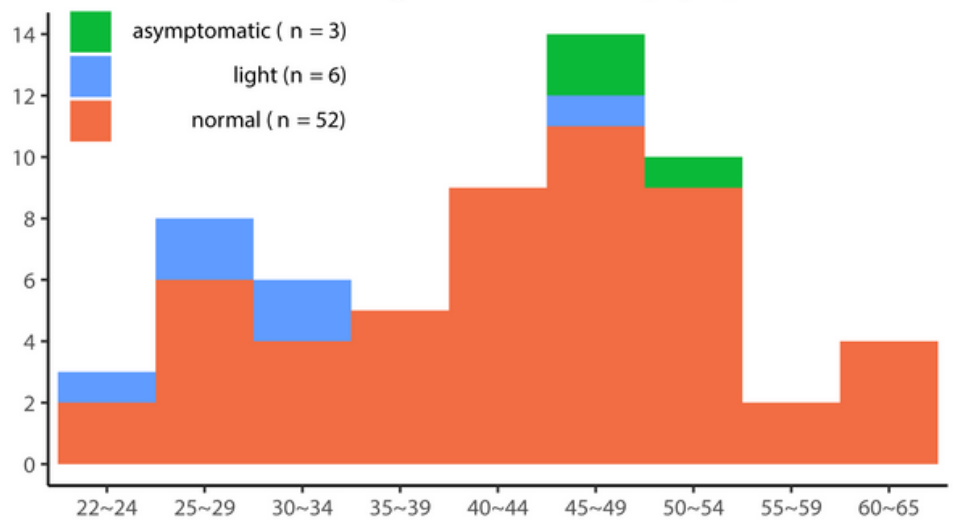

(c) the number of depression symptoms

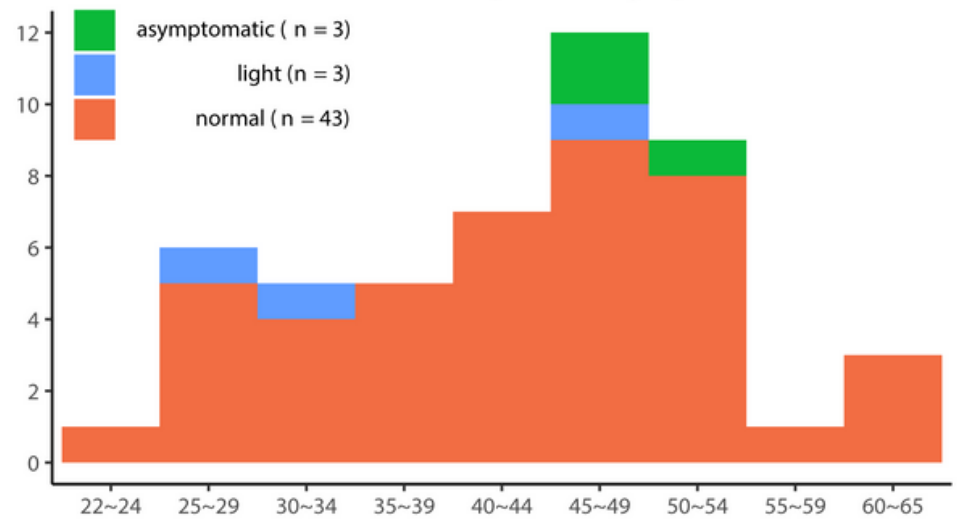

(b) the number of state anxiety symptoms

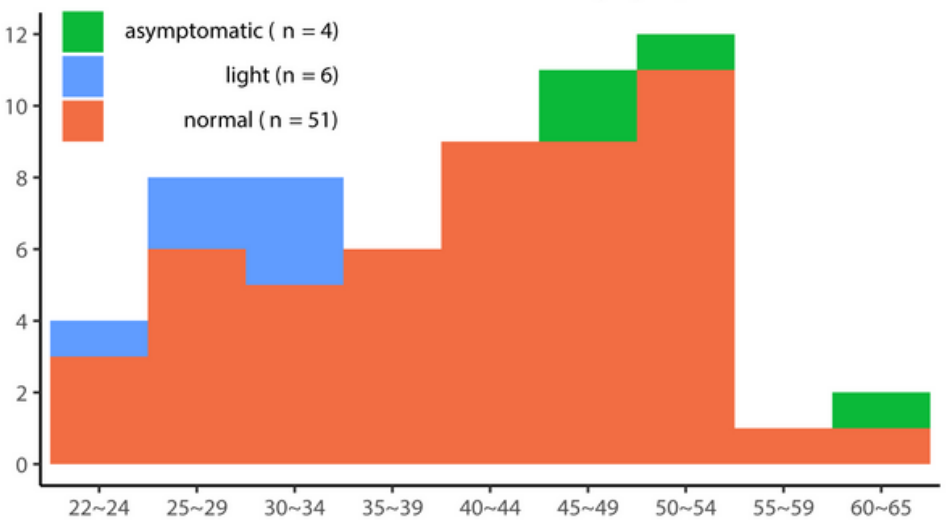

(d) the number of PTSD symptoms

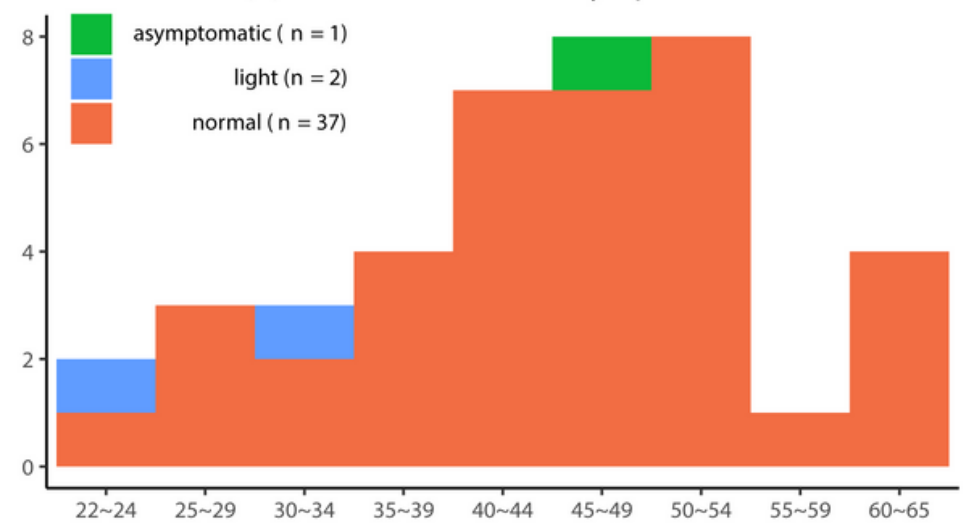

Figure 1

Prevalence of psychotic symptoms among different types of infection. Note. The number of positive psychotic symptoms (generalized anxiety, state anxiety, depression, PTSD) in different age groups among different types of infection. 